University of Warwick institutional repository: http://go.warwick.ac.uk/wrap This paper is made available online in accordance with publisher policies. Please scroll down to view the document itself. Please refer to the repository record for this item and our policy information available from the repository home page for further information.

To see the final version of this paper please visit the publisher's website. Access to the published version may require a subscription.

\author{
Author(s): Cecily Jones \\ Article Title: "If this be living l'd rather be dead": Enslaved youth, agency \\ and resistance on an eighteenth century Jamaican estate \\ Year of publication: 2007 \\ Link to published \\ version: http://dx.doi.org/10.1016/j.hisfam.2007.08.002 \\ Publisher statement: None
}




\section{"If this be living I'd rather be dead": enslaved youth, agency and resistance on an eighteenth century Jamaican estate.}

On the evening of $1^{\text {st }}$ November 1771, Thomas Thistlewood Esq, proprietor of Breadnut Island Pen, situated in the Westmoreland town of Savanna-la-Mar, exasperatedly chronicled in his journal his increasingly tense relationship with Jimmy, his enslaved sixteen year old house boy. That morning, on rising from his bed, Thistlewood was incensed to discover that during the night, Jimmy had been "throwing the fire about the cook room,” potentially causing ruinous damage to Thistlewood's house, and endangering the lives of Thistlewood and his enslaved domestics. ${ }^{1}$ Enraged by Jimmy’s recklessness, Thistlewood soundly flogged the youth. There the matter might have rested, but to Thistlewood's consternation, an unrepentant Jimmy became "very impudent” roundly declaring that "if this be living he did not care whether he lived or died, \&c”. His rage stoked by Jimmy’s open defiance, Thistlewood heaped further punishment upon the hapless youth, ordering him put into the bilboes for the rest of the day. The next morning, Jimmy was released and sent back to his household duties, though not before receiving another brutal flogging. Thistlewood, as was his wont, did not refer to this incident again, and neither did he offer reflexive commentary on Jimmy's angry denunciation of the brutal dehumanising system that kept him enslaved in Jamaica. We therefore do not know the specific circumstances shaping Jimmy’s firing of the cook room. Was it a drunken accident, or was it an attempt to kill his cruel and violent master? In the absence of Jimmy's own account of the incident, we are left forever without answers. We do know however, that this episode was not the first time that Jimmy's behaviour had caused him to feel the sting of Thistlewood's whip. Neither was it the first 
offence that involved fire. The previous year, on $1^{\text {st }}$ May 1770 , Thistlewood had flogged Jimmy for committing a similar offence - burning a hole in the piazza while inebriated, and further, for his general "impudence, laziness, carelessness, lying, etc. etc.”

The relationship between Jimmy and Thistlewood had not always been marked by tension. For the first two years following Thistlewood's purchase of Jimmy in 1765, the master-slave relationship was amicable. To Thistlewood's seeming bewilderment however, the onset of adolescence coincided with a marked deterioration in their relationship, as the formerly compliant Jimmy began to push against the bonds of his enslavement, and to contest Thistlewood's authority over his body. Thistlewood's savage thrashings failed to check Jimmy's challenges to his mastery, serving only to foster within him an obdurate rebellious spirit, as the catalogue of infractions followed by punishments indicates. We can discern in Thistlewood's chronicling of Jimmy's transgressions and his own savage responses a growing sense of disappointment as Jimmy matured from childhood to adulthood and as he strove to assert some semblance of control over his own life.

This paper explores adolescent life on the Jamaican estate of Thomas Thistlewood in the late decades of the eighteenth century. One reason for looking at this issue on this estate is that we can get relatively ample data about master slave relations from Thistlewood's diaries - the most extensive commentaries made by a slave owner about enslaved people in eighteenth century plantation America. Thistlewood gives us especially good information about adolescence because he placed a good deal of importance on buying enslaved people when young and thus more able to be coerced into becoming pliable slaves. Slavery was, as many historians 
have shown, a system of control and the control of enslaved youth was as much a component of that system as the control of adults.

Slaveowners knew that young and old could resist slavery. Early in his Jamaican career, Thistlewood heard from Wannica about an attempted shipboard rebellion during the Middle Passage and the critical role performed by young children in the conspiracy. Wannica told Thistlewood that in "the ship she was brought over in, it was agreed to rise, but they were discovered first. The pickaninies [children] brought the men that were confined, knives, muskets, and other weapons.” (Burnard 2005, p.5) Thistlewood certainly did not appear to find the involvement of children in the resistance movements of the enslaved unusual. During the infamous 1760 Tacky’s rebellion, Thistlewood approvingly noted Colonel Spragg's resolve to immediately put to death any rebel who fell into his hands. As Thistlewood noted of Col. Spragg's plan to deal with the rebels in his journal on $17^{\text {th }}$ July 1760 , "He says he is sent to destroy the rebels \& destroy them he will, to the utmost of his power, except women and children.” That Thistlewood did not comment on the presence of children among the rebels suggests that their involvement was not extraordinary. Nevertheless, Thistlewood believed young people more malleable than adults, even though his adolescent labour force frequently tested the limits of his mastery. Thistlewood's journal not only offers rich insights into the processes of transformation of enslaved children to adolescents and mature adults. It also sheds light on enslaved youth and their negotiations with, manipulations of, and resistance to the master-slave relationship. This paper argues that far from being the passive objects of planter mastery, enslaved youth were active agents shaping their own histories. In particular, I explore these issues through an analysis of the dynamics of the relationship between Thistlewood and Jimmy his house boy. Thomas Thistlewood was an exacting 
manager and owner of enslaved peoples, brutal and savage in his exercise of control and authority (Hall 1989; Burnard 2004). Old and young alike felt Thistlewood's wrath. In 1766, eleven year old Jimmy and twelve year old Bess, both received severe floggings after their childish curiosity got the better of them. Thistlewood discovered that the two had tampered with his watch, and had accidentally broken the hour hand, earning Jimmy his first flogging.

\section{Youth, Enslavement, Punishment and Resistance}

Thistlewood's journal offers unparalleled insights into Caribbean slave society. (Burnard 2004, p.24) Written over a period of nearly 40 years, Thistlewood's journal provides rich insights into myriad aspects of the daily lives of enslaved peoples as they struggled to create meaningful existences in brutal and dehumanising conditions. But Thistlewood's journal also bears powerful testimony to the determination of enslaved Africans to adapt to, and survive within a sadistic and terrorizing system. Thistlewood's sadism proved unable to extinguish his enslaved people’s longings for freedom. Men and women, old and young, constantly tested and pushed against his authority, risking humiliating, painful and cruel punishment, and even death. All but the very young, or the very old and infirm, persistently challenged his authority, though the means by which they did so varied along a continuum from passive to active resistance.

Opposition to Thistlewood's authority began in adolescence, and continued into adulthood. While the historiography of enslaved resistance has illuminated the complexity of enslaved resistance in an exploitative and oppressive system, it has yet to specifically address the ways in which young people responded to enslavement. Childhood and adolescence represented critical stages in the lives of enslaved 
children. It was during these life-stages that young people were inculcated with the racialised ideologies of the wider social order, gained insight into the value systems of their society, were socialized into acceptance of their unfree status, prepared for their future roles as labourers, and developed strategies of resistance.

Enslaved parents attempted to create a 'normal' childhood for their offspring, offering them comfort and equipping them with strategies to survive the rigours of enslavement. Though mediated by their relationships with their owners, enslaved parents tried to protect their children from the harsher aspects of enslavement. The surviving narratives of formerly enslaved people suggest that enslaved childhood represented a contested terrain as children were caught up in subtle power plays between parent and owner, as each sought to assert authority over the body of the enslaved child (Jones, 2006, p.19). But sale and separation of family members deprived many young enslaved children and youth of the solace and security of family. Though many children were absorbed into the wider enslaved community, some children, such as Thistlewood's Jimmy, were left to fend for themselves, with no parent to intervene on their behalf. Jimmy's position as a waiting boy living in Thistlewood's house, with few other domestic slaves around, further isolated him from the enslaved community on Thistlewood's estate.

As Wilma King has noted, enslaved youth were no more protected than adults from the harsh brutalities of slavery, and they too suffered the indignities inflicted on adult enslaved. (King, 1995, p.91) Enslaved youth were subjected to the range of humiliating punishments suffered by their parents - they were chained, manacled, whipped, confined in stocks and bilboes, murdered and executed. Mary Prince, the only enslaved woman known to have written a first hand account of the enslaved 
experience in the British Caribbean provides painful testimony of the cruel ill treatment of enslaved youth. At the age of twelve, Prince was forcibly separated from her family and sold to a succession of owners. Her first owners were exceedingly ruthless. Prince recalled their perverse and capricious daily floggings of Cyrus and Jack, two young house-boys. The floggings were so severe that their skin was left 'ragged and raw” (Salih 2000, pp.14-15). Prince experienced similar cruelty at the hands of masters and mistresses and soon acquired a range of strategies that enabled her to survive enslavement. Some adolescents went much further, utilising more violent methods of resistance. Slave proprietor Matthew Lewis, also of Westmoreland parish, argued that the abolition of the slave trade in 1807 tempered the previously tyrannical behaviour of slave-owners. Yet he recalls attending the trial of a 15 year-old servant girl, Minetta, who was charged with the attempted murder by poison of her owner. Minetta's crime was compounded by her refusal to show any remorse. When condemned to death, “[Minetta] heard the sentence pronounced without the least emotion; and I am told that, when she went down the steps of the court-house, she was seen to laugh.”(Lewis 1999)

Some children's fear of punishment could be sufficiently potent for them to take the decision to end their own lives. Thistlewood recorded on 22 September 1769 the suicide of "a little mulatto boy, belonging to Mr. Oliphant [who] killed himself with Laudanum having lost some money at [the] bay.” Enslaved girls were especially vulnerable to the sexual predations of white males. Thistlewood was a 'sexual opportunist' who with impunity routinely abused women on the plantations he managed and owned, sometimes forcibly initiating girls as young as thirteen into exploitative sexual relations (Burnard, 2004,p.158). Somewhat hypocritically, given this behaviour, Thistlewood reported on 11 August 1782 a neighbourhood rumour 
about the sexual perversity of his friend and ex-employer John Cope 'who kicks Mrs C. out of bed \& openly takes girls of 8 or 9 years old, \&c \&c.” (Hall 1989, p.?) Tara Inniss argues that enslaved girls were not the only victims of sexual abuse by planters. Young enslaved males could be equally vulnerable to the sexual predations of their owners. (Innis 2005) Certainly, although women and young girls were the objects of Thistlewood's sexual predations, his punishments verged at times on the homoerotic, most explicitly in his one-time favoured punishment, 'Derby’s Dose', which involved forcing a male slave to defecate in the mouth of another. Denied legal protection, physically unable to protect themselves, and in the face of their parents' inability to protect them meant that enslaved children represented the most vulnerable members among their community. (King, 1995, p. xx) Yet, as Thistlewood no doubt understood, in spite of their biological immaturity, enslaved children were as likely as adults to actively opposed their bondage once they reached understanding of their enslaved status and condition.

\section{Problematising adolescence in slave societies}

As a group, enslaved children left behind few personal testimonies of their experiences. Caribbean historians have only the narratives of Mary Prince and Olaudah Equiano with which to reconstruct the childhood experiences of enslaved youth. Much of what we know about enslaved children and their childhood experiences has to be gleaned from scattered references in the writings, correspondence of slave-owners and contemporary observers. Because adolescents represented a significant proportion of Thistlewood's estate's labouring population reflecting his preference for younger workers - , they, more so than younger [nonproductive] children were the objects of his managerial - and sexual - attentions. As 
historians of childhood and adolescence remind us, the 'adolescent' is a product of history, a socio-cultural constructed category invented in the 1890s to describe the period between the onset of puberty and full adult maturity, generally marked by entry into the economic sphere. Adolescence represents a transitional life phase that allows the young to prepare for adjust to their future responsibilities. But as King argues, the concept itself is anything but universal, for in the nineteenth century, "the time lag between these two intervals functioned differently for white boys and girls, poor or wealthy and blacks.”(King 1995, p. xviii)

Exploring the meanings of adolescence in the context of Caribbean slave societies reveals the arbitrariness of the beginning and endpoints of this category. While white male children of slave-owners were not considered to have reached adulthood until the age of 21, enslaved youth experienced a more truncated period of adolescence. Indeed, King suggests that enslaved children neither enjoyed a childhood or adolescence, as slavery demanded their passage into the adult world of labour while still biologically immature (King, 1995, p.xx). On Thistlewood's estate, children were integrated into the labour force from an early age, with youngsters of six and seven years of age expected to perform labour commensurate with their physical capacities, e.g. weeding, minding poultry. Some were put to learn a craft while barely out of their infancy. Bristol's childhood effectively ended on $13^{\text {th }}$ February 1780 when he was $7 \frac{1}{2}$, when Thistlewood "ordered [him]...to go with [his son] John to learn to be a carpenter for me. He is just $4 \mathrm{ft} 1$ inch high...marked him on the left shoulder.”

By contrast, Thistlewood's own son Mulatto John, though clearly lacking scholarly aspirations, received schooling until the age of 15 , when his father deemed 
him ready to begin an apprenticeship. Enslaved males commonly were considered to have reached full adulthood on entry to the labour force around the age of 16 , though for girls, the onset of the menarche - around the age of 12/13 - generally signalled their entry into adulthood. As we shall later see though, Thistlewood's own system of youth/adult classifications was informed by his own subjective requirements. While recognising that the concept of adolescence had no purchase in eighteenth century Jamaica, for analytical purposes, and cognisant of the inherent problems in so doing, I nevertheless define as adolescents all individuals between the ages of twelve to twenty.

\section{Becoming an enslaved youth: Thistlewood's Jimmy}

Thomas Thistlewood arrived in Jamaica in 1750, intent on making his fortunes through the agency of slavery. His relatively straitened circumstances prevented his immediate entry into the ranks of Jamaican planters. He was forced to hire his services as an overseer at a series of estates, before he could eventually accumulate the resources to establish his own property. By 1760, Thistlewood was an experienced manager of enslaved people and agricultural production. His future success as a planter, he well knew, rested on his ownership of enslaved people. His experience as an overseer of slaves prepared him well for investing in a potentially risky market. The year 1756 marked Thistlewood's entry into the ranks of Jamaican slave-owners. Three days into the New Year, he made his first foray into the slave market with the purchase of a young Ebo male, whom he named Lincoln and who cost $£ 43.00$. Two years later, in February 1758, Thistlewood added to his portfolio, purchasing "two New Negro men, at 51 pounds each, and a New Negro girl at £46 pounds.” Of his three 1758 purchases, it was young Abba who was to be a continuous presence in 
Thistlewood's life, surviving beyond his death in 1786. This however, is not Abba's narrative, though we will encounter her again throughout this paper.

Thistlewood's ambitions to become an independent proprietor did not fully materialise until 1767, but meanwhile he set about building his labour force for his future estate. He set out in his journal his strategies for the purchase of enslaved people.

In regard to buying of Negroes, I would choose men-boys and girls, non-exceeding 16 or 18 years old, as full grown men or women seldom turn out well; and beside they shave the men so close and gloss them over so much that a person cannot be certain he does not buy old Negroes (Hall 1989, p. 119).

His acquisition strategy - youth over maturity - was sound. In purchasing young enslaved people - ill-health and premature death not withstanding - Thistlewood could be assured of wresting many years of productivity and profits from labourers yet to reach the prime of their lives. In addition, he could train them according to his own practices, believing them more tractable than older slaves. In line with this, his next investments were three young adults purchased in April 1761 - the oldest of whom was Nanny, aged about 21, and two boys Ceasar, and Solon, aged about14 and 16 respectively. Thistlewood rounded off 1761 with the purchase of six more enslaved Africans: two men (Will (aged 25), Dick (22); one boy, Pompey (age 14); and three girls, Maria (15), Sukey (14) and Coobah (15). Months later, in April 1762, Thistlewood made a further purchase, Sally, a Congo girl, estimated as 9 or ten years old. 
Lack of capital prevented further forays into the slave markets until 1765, when Thistlewood's plans for achieving independent proprietorship neared fruition. On Monday $29^{\text {th }}$ April, Thistlewood went on board a ship newly arrived from Guinea and bought ' 10 New Negroes: 2 men [£56 per head], 2 men-boys and two young women at $£ 54$ per head, three girls at 52 per head and 1 boy at $£ 51.00$ per head.' (Hall 1989, p. 135) The oldest of these were Syphox, aged either 19 or 20 years; Cudjoe, a Coromantee man aged about 19 years; and Myrtilla, aged about 19. Three were boys: Chub, aged about 13 or 14; Bristol, aged about 17; and Jimmy, aged about 10 or 11 years old. Four were girls: Phoebe, aged about 12 years; Peggy, a woman aged 16 or 17, Franke, a woman-girl aged about 13, and Damsel, a 'woman-girl', aged about 13. Fearing that they might fall victims to a local smallpox epidemic, Thistlewood quickly despatched his new purchases to their new home, where they were fed a meal of bread and salt fish, and branded with Thistlewood's mark. With the exception of Jimmy (destined to serve as Thistlewood's personal attendant in the Big House), they were all assigned to live with older, enslaved adults whose role it was to assist their adjustments to their new conditions. Their seasoning period was short; within a few days of arrival in Jamaica, Thistlewood, anxious to exploit their productive capacities, had his newly enslaved labourers put to work in the fields. Perhaps because of his biological immaturity, Jimmy, the youngest of Thistlewood's new cohort, escaped the fate of his shipmates, and was instead taken into Thistlewood's house. Here he lived for much of his adolescence, serving Thistlewood as personal attendant and general houseboy. Living in such close proximity to Thistlewood represented a double-edged sword. As a house boy, Jimmy enjoyed a relatively privileged status but was also subject to Thistlewood's close scrutiny. Yet, although for many years, Jimmy 
represented a permanent presence on Thistlewood's daily landscape, we know very little about him, beyond the few glimpses captured in Thistlewood's journal.

Jimmy emerges within Thistlewood's diary shorn of history. Thistlewood displayed marked disinterest in the personal lives of the enslaved. In his early years in Jamaica, Thistlewood acquired considerable knowledge about African cultural traditions and customs, but regrettably recorded little about the former lives of his new purchases. We know nothing about Jimmy's previous life, the events that led to his capture and subsequent enslavement and how he survived the traumatic middle passage, a crossing that often proved too hard even for adults. Though its authenticity has been subject to critique by Vincent Carretta, Olaudah Equiano’s narrative of his childhood in Essaka, Nigeria, perhaps brings us the closest that we can come to understanding the undoubtedly terrifying series of events that subsequently led to Jimmy's purchase by Thistlewood. (Equiano, 1789; Carretta, 2007) What is certain is that Jimmy arrived in Jamaica bereft of family and kinsfolk; chained, weary in body and soul from the long perilous sea voyage; consumed by terror, bewilderment, anxiety, and homesickness; apprehensive of his future and wary of the white people among whom he found himself. Jamaica must have appeared to Jimmy a land of strange new sights, sounds and smells; of rough, pale skinned people who poked and prodded his bodily orifices, while ordering him to strip in an unfamiliar tongue; of subjugated African women and men, some of whom spoke his Twi language, and others who spoke in unfamiliar dialects.

Indeed, beyond some brief vital statistics, Thistlewood tells us nothing about of the biographies of his new purchases. Even their African names are lost to us, for 
Thistlewood commonly renamed the enslaved people he purchased. The young male on whom he bestowed the name 'Jimmy' he described as “a boy, about 10 or 11 years, 4ft 5 6/10 ins (Coromante or Shante).” Thistlewood habitually noted the presence or absence of scarification patterns “country marks” denoting ethnic and tribal affiliation, marital status and life stage, inscribed on the faces and bodies of new purchases. That Jimmy, alone among the newly enslaved males, bore no scarification marks suggests his immaturity. In traditional Akan society, the life stage ceremony denoting the transition from childhood into adulthood also included bodily and facial scarification, indicating the child's passage into the adult world. Thistlewood tells us nothing about the processes of Jimmy's acculturation to Jamaica, so we do not know how the young boy responded to the very many adjustments required of him. How, for instance, did he acquire English language skills, and from whom? Who taught him the duties of a personal attendant - Thistlewood himself, or Lincoln, his predecessor? Who, if anyone cooked, washed and cared for him? Who offered him comfort in moments when he was seized by bouts of homesickness? Who taught him the meanings of his enslaved condition? During his first eighteen months in Jamaica, Jimmy remains an elusive figure within Thistlewood's household. Thistlewood rarely mentioned Jimmy, beyond cursory notations recording some aspect of Jimmy’s work routine - “Jimmy accompanied me to the Bay”, “Jimmy found a knife in the road”, “Jimmy to Mr. Hayward with a letter and mudfish.”

Thistlewood's journal, however, does shed some light on Jimmy the young labourer. His duties were probably common to most house-children who were generally put to relatively light labour in and around the big house - pulling weeds, feeding poultry, collecting eggs, carrying water to workers in the field, assisting in 
meal preparation, serving meals, light cleaning, and helping in the production of sundry household items. As Thistlewood’s waiting boy and personal attendant, Jimmy's roles often took him beyond Thistlewood's estate, a 'privilege' probably not enjoyed by other children. Within months, astride “Mackey horse”, Jimmy was employed almost daily delivering correspondence, messages, food, books and gifts between Thistlewood and his circle of friends, neighbours, business partners, and local merchants and traders. He delivered horses to the blacksmith for shoeing, accompanied Thistlewood's mulatto son John to and from school, and went on hunting trips with Thistlewood, who taught him to shoot teal. As he gained Thistlewood's trust, he was sent weekly to deliver sums of money owed by Thistlewood to other local proprietors for the hire of their labourers.

Jimmy provided Thistlewood with both labour and self-esteem and status. His master's ambition to become an independent proprietor was equally matched by his desire to elevate his social status. His ownership of enslaved peoples represented the route through which he could make conspicuous that standing. Always concerned with appearances, Thistlewood clearly derived a not inconsiderable measure of pride when he attended militia exercises with his waiting boy in attendance. Dressed in a specially made suit, and carrying Thistlewood's guns, Jimmy's presence at the barracks represented the successful fulfilment of Thistlewood's long-desired entry into the ranks of Jamaican slaveholders. His ownership of enslaved people represented not merely the source of his profits, but, as Burnard suggests, also signalled his status as a propertied man of some standing, above the ranks of unpropertied white servants. (Burnard 2004, p.197) 
Wilma King remarks of enslaved youth that, “One of the greatest disruptions in their lives was the quantum leap from childhood into the world of work.” (King 1995, p.22) Yet creole children born to enslaved parents at least had one advantage over children newly purchased from Africa, many of whom had only previously known freedom. Creole children at least had a few short years to become cognisant of their status, and moreover were prepared by their families and community for their future labouring roles. Some newly purchased children may have experienced enslavement in their homeland, but they could not have been prepared for the totalising force of Caribbean slavery. Jimmy was catapulted out of childhood straight into the adult world of labour. Hence, Jimmy’s situation raises many questions about the psychological damage suffered by young people not yet or barely into puberty, taken from their families and homelands, and forced into labour on Caribbean plantations. Studies of enslaved families reveal the importance of parents in preparing children for their future adult roles within the enslaved labour force. Thistlewood tells us nothing about how Jimmy and his ship-mates adapted to life as enslaved people, but their experiences must have impacted severely on their psychological health. Within months of her purchase, for example, Thistlewood reported that Jimmy’s shipmate Peggy, aged around 17, seemed “disordered in her senses” and though she apparently recovered, suffered further bouts of psychological ill-health(Hall 1989, p.140). Peggy's increasingly erratic behaviour probably stemmed directly from the trauma of displacement and enslavement.

\section{Contesting the master-slave relationship}

Historians have long suggested that enslaved domestics fared qualitatively better than fieldworkers, receiving better food, clothing and shelter, advantages from 
which Jimmy probably benefited. Moreover, as an 'orphaned' child, it is likely that Jimmy attracted the sympathies of Thistlewood's female domestics - Abba, Bess, and Phibbah, Thistlewood's mulatto mistress. Thistlewood's journal offers scattered hints that Jimmy and Phibbah developed a close relationship, she possibly, out of compassion for an effectively orphaned child. Certainly, in later years, as Jimmy and Thistlewood became locked in conflict, Thistlewood would berate Phibbah for her readiness to cover for and excuse Jimmy’s behaviour. Bess, around the same age as Jimmy, was a particular friend and was involved in events that led to Jimmy receiving his first flogging. Abba, although older by some years, and already a mother, also probably played a mother-figure role in Jimmy’s life. Within a few years, however, they embarked on a more intimate relationship that was a source of ongoing conflict and sexual rivalry between Jimmy and Thistlewood.

. Thistlewood frequently complained about the woeful work ethic of his enslaved people. He criticised their deficiencies as labourers, their laziness, their propensity to malinger and their careless and shoddy work practices. In his first years in Thistlewood's household, Jimmy's performance of his duties rarely gave his master cause for complaint. Indeed, Thistlewood and Jimmy appeared to share a relatively amicable relationship. As Burnard has noted, despite his savagery towards miscreants, Thistlewood shared affectionate relationships with some among his enslaved community, as was evident in his relationships with Phibbah and her family, and with Lincoln, Jimmy’s predecessor as personal attendant. He suggests that Lincoln was a special favourite, possibly because he was Thistlewood's first purchase. (Burnard 2004, p.196). Jimmy similarly shared a favoured position. He was the youngest of Thistlewood's 1765 purchases, lived in very close quarters to Thistlewood, had earned Thistlewood's trust, and impressed his master with his ability to quickly learn 
new skills. Thistlewood taught Jimmy to ride, shoot and hunt (was especially proud when after a few trial shots, Jimmy downed 3 teal). He made Jimmy gifts of old clothes and trinkets, and permitted him to accompany Phibbah, Mulatto John and other favourites to attend races and circus shows. Moreover, he entrusted Jimmy with Mulatto John's care. By 1767, Jimmy was aged about 12 and had been enslaved in Thistlewood's service for nearly 2 years. Apart from the single incident over Thistlewood's broken watch, he had remained in Thistlewood's good graces. But in this year, for reasons that Thistlewood does not elaborate on, the seeds of a conflictual master-slave relationship were sown.

The precipitating factor in what would become a long-lasting acrimonious relationship between Thistlewood and Jimmy occurred on $28^{\text {th }}$ February 1767 as the cotton harvest began. Harvesting cotton represented one of the most labour intensive tasks on an estate, often involving house-workers and artisans in addition to field workers. Needful of as many hands as possible, Thistlewood took Jimmy away from his usual household duties, and pressed him to work picking cotton with the field gangs. Unaccustomed to even the lightest field labour, Jimmy found cotton picking physically demanding. His strength soon gave out as the backbreaking work took its toll on his constitution. The following morning found him so weak that Thistlewood was forced to send him to the sick-house to recover. It was not until June 1767 that Thistlewood repeated the experiment. Whether through genuine oversight, tired after a long day of demanding labour, or in a fit of pique at his enforced day in the fields, that night Jimmy neglected to properly pen Thistlewood's horses, allowing them to escape. Angered by his negligence, Thistlewood gave Jimmy his second ever flogging. Although the punishment stemmed from Jimmy’s carelessness, one senses that Thistlewood acted from other motivations. For reasons that he does not elaborate, 
he was by now becoming more watchful and critical of Jimmy’s conduct and behaviour. He seems to have interpreted Jimmy’s negligence as a sign of increasing readiness to challenge his authority. Jimmy clearly objected to his temporary relegation to field labour. Possibly, he wilfully allowed the horses to break free. In doing so, he implicitly conveyed to Thistlewood that he would resist all future attempts to force him into field labour. Whatever the truth of the matter, it is significant that Thistlewood did not attempt to send Jimmy into the fields again for some years.

\section{Rum and resistance}

Thistlewood's journal leaves us in no doubt that by 1767 he had begun to find Jimmy’s behaviour increasingly vexatious. His anger was fuelled by Jimmy’s growing fondness for rum. His involvement in the theft of some rum earned him his second flogging of the year on $17^{\text {th }}$ August, although Thistlewood believed Jimmy had been coerced into the plot by Prince, an older male. Perhaps Thistlewood felt some remorse in flogging Jimmy, for just over a week later, he presented Jimmy with 4 yards of osnabrig material, enough to make him two new pairs of breeches. In fact, though, Thistlewood's suspicions of Jimmy's involvement in thieving rum may have been well-founded. On $3^{\text {rd }}$ September, riding home from visiting Paradise Pen, Thistlewood noticed that “Jimmy was drunk.” In mid-March 1768, Thistlewood forced Jimmy to wear a collar all day for lying to him. Two months later, on $21^{\text {st }}$ May 1768, for reasons unknown, Thistlewood “flogged and put a collar about Jimmy’s neck”. Relations were not always unpleasant: on $16^{\text {th }}$ June 1768 Jimmy gave Thistlewood a land turtle. But the truce was short-lived, as Thistlewood became increasingly intolerant of Jimmy’s infractions. On $26^{\text {th }}$ September, again for causes 
unknown, Jimmy incurred Thistlewood's wrath and was put to bill the pastures for two days. Thistlewood despaired of Jimmy, ruefully commenting that "He is ruined with laziness.” Later that year, on November $23^{\text {rd }}$, Jimmy was made to sleep in the bilboes.

Thistlewood's increasing disillusionment with Jimmy's stemmed not only from his flagrant challenges to his mastery, but to his waiting boy's escalating dependence on alcohol. Alcohol flowed relatively freely on Thistlewood's estate; he used rum as an incentive to work, as rewards for good behaviour, and made his enslaved people gifts of rum at Christmas and other holidays. Tellingly though, he refrained from providing Jimmy with alcohol, although its apparent ubiquity enabled Jimmy to procure his own supplies by various means. By the age of 15, Jimmy was frequently inebriated, sometimes with calamitous results, as when he drunkenly burnt a hole in the piazza floor, incurring a severe flogging for his actions and for his 'impudence’ in showing no remorse. Jimmy’s fondness for rum would continue to be a recurrent source of strain in the master-slave relationship. The sources of Jimmy's descent into alcoholism are worth speculation, though Thistlewood refrained from reflection on the underlying causes of Jimmy’s dependence. While we can never know these factors with certainty, several answers suggest themselves. Of course, Jimmy’s fondness for rum might simply be reducible to adolescent high spirits [no pun intended] but I would argue that equally, alcohol provided for Jimmy a psychological escape from the deadening pains of enslavement. Frederick H. Smith argues the widespread use of alcohol among African-born enslaved people enabled them to deal with the challenges of enslavement, though ultimately, this became a self-destructive coping mechanism. (Smith, 2006). His suggestion that African-born enslaved were more likely to develop alcoholic tendencies in the absence of a 
supportive family structure may help to illuminate the orphaned Jimmy’s own dependency. Moreover, his increasing reliance on alcohol is suggestive of the problems that Jimmy had in reconciling his various selves - the good servant, and later, the aspiring lover, the independent man. Certainly, as he matured into early adulthood, and as his conflicts with Thistlewood over his labour, his sexual life, and his own desire for agency intensified, his reliance on alcohol deepened - despite Thistlewood's best effort to curtail his supplies.

Jimmy’s resistance to Thistlewood's mastery reached its nadir in the opening years of the 1770s. In 1770, Jimmy was aged around 15. He had served as Thistlewood's personal attendant and waiting boy for five years. Now on the cusp of manhood, Jimmy often resisted Thistlewood's authority, though usually through subtle acts of insubordination rather than outright defiance. He was frequently careless in his duties; he lied to Thistlewood; he stole food and rum; and was frequently `impudent.’ When sent to deliver messages or fetch water, he often returned late and drunk. Nevertheless, Thistlewood continued to tolerate Jimmy’s behaviour, rarely bothering to send a search party after him, as was his usual practice when enslaved people absented themselves. Moreover, Thistlewood kept him in his privileged status as his personal attendant until 1774, when, finally tiring of Jimmy's insubordination, he demoted him to the ranks of the field slaves - though still on occasion employing him as messenger-boy.

How can we understand Jimmy’s increasingly defiant conduct? Was it typical adolescent rebellion to established authority or a coping mechanism to deal with the psychological trauma of enslavement? Thistlewood's silence on such matters leaves us able only to speculate. But it is not unreasonable to conclude that resentment of his 
enslavement was important in shaping Jimmy's behaviour. Though he was a privileged slave, he saw how Thistlewood treated other slaves, such as the 'incorrigible runaways’ Coobah and Sally, and saw how these women grasped every opportunity to 'pull foot' from Thistlewood's estate, despite knowing that when caught, they would be severely punished and probably sexually violated. His observations of the pervasiveness of enslaved attempts to oppose and manipulate the system may have encouraged him to assert himself. As he became an adolescent, the previously compliant and loyal Jimmy was less willing to accept his subjugation. Jimmy’s self-assertion angered Thistlewood. In what would become a constant refrain, Thistlewood wearily noted that the once obedient and dutiful house-boy had become irrevocably corrupted by “laziness, carelessness, lying etc.” Jimmy’s own acts of insubordination did not represent a substantive challenge to the institution of slavery - Thistlewood's people undoubtedly knew that short of outright rebellion, their opposition had little chance of overthrowing the system - but these mundane and routinised acts of defiance served to dilute Thistlewood's absolute mastery over Jimmy’s body and labour.

Adolescence represented a critical stage for Jimmy - it was during this period that he most vehemently began to assert his claims for independent humanity from Thistlewood, and it was during this period that his patterned responses to enslavement that he would carry into adulthood were laid down. The difficulty presented in understanding his behaviour is to untangle that behaviour that could properly be described as 'typically' adolescent from that provoked by his conditions as an enslaved youth. In some respects, Jimmy’s adolescence rebellious acts mirror those of Mulatto John, Thistlewood's son, who like Jimmy, proved a source of disappointment to Thistlewood; John, as instance, truanted from school and later his place of 
apprenticeship, while Jimmy shyed away from work, often deserting his post. Yet I would argue that their respective youthful rebellions stemmed from different sources. John's troubled adolescent relationship with Thistlewood was probably rooted in his identity as the mulatto son of a free white father and an enslaved mother, owned by his father. That he more often appeared comfortable in the company of blacks does suggest a desire to retain some distance from his father, with whom he did not enjoy a comfortable father-son relationship. To this extent, the interracial relations of slavery also then exerted some psychological damage on John, even though his was a more privileged existence. However, I think that Jimmy’s adolescent rebellions cannot be easily separated from his experiences as an enslaved youth, and should instead be viewed as the outcome of the psychological damage caused by the trauma of capture, separation from and loss of family, the Middle Passage, and his experiences of enslavement. ${ }^{2}$ Ultimately, Jimmy’s behaviour should be understand not merely as normative adolescent rebellion, but as his construction of psychological defenses that enabled him to reject dependency on his master, while at the same time to withstand and survive the brutalities and indignities of enslavement.

\section{Sexual Rivalry and the master-slave relationship}

Relations between Thistlewood and Jimmy deteriorated markedly in 1771, when Jimmy formed a relationship with Abba, one of Thistlewood's favourite sexual conquests. On $31^{\text {st }}$ March 1771 Thistlewood laconically noted "it is suspected that Abba keeps Jimmy, for he is asleep and stupid all day, \& the negroes remark the reason”. Suspicions were confirmed when on $1^{\text {st }}$ May, Thistlewood sought out Jimmy in his usual sleeping place in the cook room, only to find that Jimmy had deserted his post. Accompanied by Pompey, Thistlewood went to Abba's house in search of 
Jimmy, and there "catched Jimmy sleeping with her." Jimmy “endeavoured to escape but I laid hold of him, put them both in the bilboes, and when light flogged them.” Thistlewood's professed himself less concerned with moral indignation at Jimmy's precocious sexuality but at how his desire for Abba had compromised his slave management: "one of the children was upon the bed with yaws, although Jimmy has never had them...and the cook room left to itself, although all the utensils in it and all the clothes in this week's wash.” Nevertheless, sexual jealousy may have played a part in Thistlewood's excessive response to a minor infraction.

Thistlewood may have resented sharing Abba with his servant. Significantly, Thistlewood increased sexual contact with Abba at the same time as Jimmy and Abba became more permanently attached. He had sex with Abba 39 times during 1771, paying her 2 bitts each time, as was his custom on having sex with enslaved women. Thistlewood insisted on showing to Jimmy that he, not Jimmy, had first rights over Abba’s body. On Saturday night, $17^{\text {th }}$ May, Jimmy, supposedly away fishing, could not be found. Thistlewood again mounted a search of Abba's house, clearly expecting to catch his errant attendant. But he did not find Jimmy, and as if to underscore his rights of sexual access to enslaved women, Thistlewood proceeded to have sex with Abba, before continuing a fruitless search of the slave quarters for his servant. Jimmy was powerless to directly challenge Thistlewood's sexual interventions. That he plainly resented Thistlewood's sexual appropriation of Abba is apparent, for his general conduct degenerated into outright insolence and defiance. Thistlewood tersely noted on June $26^{\text {th }}$ that Jimmy "is daily becoming more careless, stupid and impudent, through Abba's encouragement”. The ménage a trios was further complicated when Abba became pregnant - neither Thistlewood or Jimmy could be sure of paternity until after the child's birth. Undeterred by Abba's pregnancy, Thistlewood continued 
to exercise his bodily rights, having sex with her only two days before she gave birth to a daughter on $17^{\text {th }}$ October. Thistlewood had reason to believe himself the father, for he described the child as “very yellow, it seems”. Abba’s baby did not live long, dying a week later on $24^{\text {th }}$ June. Perhaps Jimmy had believed himself to be the child's father, for on the night of the baby's death, he became so nosily belligerent that Thistlewood had him locked up in the cook-room. Thistlewood chose to blame Jimmy for the death of Abba's child, through "his disturbing them during the night". Released from confinement, Jimmy's anger and frustration remained unabated for he hurled at Thistlewood “many impudent words, etc.” Despite further punishments, he persisted in displaying highly disturbed conduct over the course of the next few weeks. On Monday $28^{\text {th }}$ October, Thistlewood noted that he "continue[d] to lock up Jimmy at nights in the cook room, yet”, but Jimmy remained defiant, seemingly immune to Thistlewood's efforts to subjugate him. On Friday $1^{\text {st }}$ November, Thistlewood discovered "Jimmy throwing fire about the cook room. And always being very impudent, saying if this be living, he did not care whether he lived or died.” Thistlewood's response to Jimmy's angry outburst was to place him in the bilboes until the next morning, when he was released, and once again soundly flogged. The next night, Thistlewood had Jimmy once again locked in the cook room.

Was Jimmy’s 'impudence’ a response to his frustration at Thistlewood’s ongoing sexual relations with Abba, and his grief at the death of a child he believed to have fathered? Perhaps Thistlewood believed that brutal punishment would eventually curb Jimmy's intransigence, but in this he was mistaken, for he soon had reason to believe that Jimmy had tried to murder him. On Friday $15^{\text {th }}$ November 1771 , Thistlewood felt unwell and before retiring to bed drank some warm beverage - lime juice, sugar and water - prepared by Jimmy. An hour later, his physical symptoms 
were so excruciating that he "verily thought that I had been poisoned, as I really believe I should had I drunk much more, tasted so strong of sublimate! Suspect [Jimmy] very, very much, he is very impudent, lazy, sly and sullen...too strong to be communicated by a tea-kettle. However, found myself full as well as I could expect, on Saturday morning.” Unusually, Thistlewood did not investigate his suspicions further, seemingly thankful to have recovered. Incredibly, Jimmy appears to have escaped punishment. We cannot know whether Thistlewood's suspicions were wellfounded, but if Jimmy, his anger still festering over Thistlewood's entanglement in his sexual relationship with Abba, had indeed sought to murder his master and sexual rival, this attempt represented especially blatant and violent opposition to his master. The years between 1771 and 1774, when Jimmy and Thistlewood shared Abba was the period in which Jimmy’s conduct was most unruly. Thistlewood complained frequently about him, suspecting him of stealing rum and porter. He was often drunk, blatantly lied to Thistlewood, absconded for hours, was careless with Thistlewood's property, absented himself from the cook-room at night to consort with the enslaved in their quarters, and cheated Thistlewood of income from the sale of goods. Yet, Thistlewood continued to display a surprising degree of tolerance towards Jimmy, until $31^{\text {st }}$ October 1772 when Jimmy absented himself from the plantation for several hours. When he returned at $5.00 \mathrm{pm}$ in a drunken state, Thistlewood put him in the bilboes. The next day, Thistlewood determined he would no longer endure Jimmy’s blatant insubordination. After releasing Jimmy from the bilboes, he flogged and pickled him and permanently demoting him from house-boy to field labourer.

Relegation to the field gang had one advantage for Jimmy. He was free from Thistlewood's constant surveillance. Consequently, he enjoyed a greater degree of personal freedom than had been previously possible living in Thistlewood's house. 
Some time during 1774, perhaps weary of sharing Abba with his master, he embarked on an affair with his old ship-mate Phoebe, then currently living with Egypt Neptune, whom Thistlewood had matched her with at the age of fourteen. Thistlewood first became aware of the affair on $11^{\text {th }}$ December, 1774 , noting in his journal that “...Jimmy wants to throw away Abba, he having long kept Phoebe slyly; Phoebe has also thrown away Neptune (or wants much to do it!) upon Jimmy’s account. A hopeful chap!” The rumours were soon confirmed. Thistlewood generally refrained from interfering in the sexual lives of his enslaved people but perhaps considering that Jimmy had undermined his authority in breaking up a match that he had ordained, or perhaps feeling it necessary to give the aggrieved Neptune a sense of redress, Thistlewood flogged both Jimmy and Phoebe "for Crim. Con. \&c. [criminal conversation].” With justice seen to be done, Thistlewood sanctioned their relationship, allowing them to set up house together. Theirs would prove to be one of the most durable and peaceful of relationships on Breadnut Island - Thistlewood noted only one incident of domestic discord between them, in April 1781, when during an altercation “Jimmy bit Phoebe’s lips, \&c.” At Thistlewood’s death in 1786, they were still living together as a family unit with their daughter, Charity, born $9^{\text {th }}$ January 1778. Characteristically though, Thistlewood continued periodically to assert his sexual rights over Phoebe, having coercive sex with her while she was heavily pregnant with Jimmy’s child. She was, in fact, one of his last sexual partners before his death.

\section{The wages of resistance}

In banishing Jimmy to the fields, Thistlewood hoped to effect a reform of his character. He still held Jimmy in some favour, entrusting him with relatively 
important responsibilities. Jimmy, however, continued as intransigent as ever. Throughout 1775, hardly a month passed when Jimmy’s conduct did not arouse Thistlewood's wrath. Yet Thistlewood frequently allowed Jimmy’s misconduct to go unpunished. On $4^{\text {th }}$ January 1775 , Thistlewood gave Jimmy some money and sent him out to buy some beef. Returning home, Jimmy attempted to short-change his master, but Thistlewood uncovered his deceit. Thistlewood merely noted the attempted deception and took no further action. Perhaps emboldened, Jimmy pushed his hand further. A month later, on $1^{\text {st }}$ February 1775 , Thistlewood irritably noted Jimmy’s desertion of his nightly post in the cook-room, "he says at Egypt (but doubtful) suspect his riding my horses.” Jimmy once again went unpunished. And Jimmy’s fondness for rum continued to be a source of strain and struggle. On the way home from dinner with his friends on $21^{\text {st }}$ March 1775, Thistlewood noticed to his consternation that "Jimmy was very drunk" and resolved to find and cut off the sources of Jimmy’s liquor supplies. Whether drunk or sober, his conduct did not improve. On $6^{\text {th }}$ April, Thistlewood again complained of Jimmy’s deceit: “[he] pretends to be not well, owing to his being up all last night, about his tricks with Phoebe.” The battle of minds continued. On June $21^{\text {st }}$ when sent by Thistlewood to sell fish and lima beans, Jimmy returned after an absence of seven hours with a mere two bitts in proceeds. On this occasion, Thistlewood flogged him, suspecting he had again been short-changed. Yet even the most severe punishment was no deterrent. His unauthorised absences were becoming habitual, and his drinking leading him into deeper trouble. On $5^{\text {th }}$ July and $22^{\text {nd }}$ August, Jimmy arrived home intoxicated, “drunk, newspaper all frumpled, and suspect one of them lost.” On the second occasion, Thistlewood angrily remonstrated with him but to his consternation Jimmy simply “walked away towards Savanna la Mar, and I saw him no more that night”. He did not 
return again until two days later. Such bold defiance could not go unpunished. Thistlewood had Jimmy "flogged, given a new bill and new hoe, and sent him, by Lincoln, to work with the rest of my negroes.” And as if to literally reinscribe his ownership of Jimmy’s body, Thistlewood had Jimmy rebranded with Thistlewood's mark on the left shoulder, noting at the same “ He measures near $5 \mathrm{ft} 3$ ins high.”

For the rest of that year and for all of 1776, Jimmy, now primarily employed as a field worker remained out of Thistlewood's immediate orbit. Indeed, once removed from close proximity to Thistlewood, Jimmy’s anger eventually eased. Certainly over the next few years, he rarely gave his master cause for complaint. Thistlewood, perhaps believing that Jimmy had learned his lesson, took him back into partial house service, employing him in the old manner to deliver messages and to attend him as he rode around the neighbourhood. Thistlewood evidently felt some degree of affection towards his wayward slave, and despite occasional grumblings about Jimmy’s laziness and carelessness continued to entrust him with jobs he considered important. He frequently despatched Jimmy to town in search of runaway or absent slaves, and when Lincoln, Thistlewood's favourite, absented himself from Breadnut Island, it was Jimmy whom Thistlewood despatched in search of him. When Thistlewood felt himself unable to carry out whippings, he appointed Jimmy in his stead, though Jimmy was reluctant to take on this role. In July 1778, Thistlewood had Jimmy flog “Driver Dick for not making the Negroes work.’ Jimmy apparently had neither the stomach or spirit for this brutal task, for he made such a poor job of wielding the whip, that Thistlewood had him flogged "for not exerting himself in flogging Dick.” On occasion, he also appointed Jimmy driver of the labour force, although again, Jimmy proved not as hard a task master as Thistlewood demanded, 
and on New Year's Eve, 1775 received a flogging for 'letting the Negroes quarrel last night.'

Explaining the master-slave relationship is difficult. Although enslaved people populate his journal, Thistlewood rarely expressed anything other than rage, anger, bemusement or indifference towards them. Even within the privacy of his journal, Thistlewood could not avow his intimate regard for Phibbah, his mistress of over thirty years, only occasionally reflecting on her unselfish acts towards himself, 'she is good', 'pity her in miserable Slavery' - but stopping short always of declaring love for her. Yet he was capable of forging emotional attachments to certain among his enslaved population. Jimmy numbered among this inner circle. When on $10^{\text {th }}$ December 1780 Phoebe and Jimmy’s seven year old son died following a brief illness, Thistlewood revealed a surprising depth of fondness for the little boy: "Phoebe’s Tony died. He was a wonderful fine boy,” an epitaph not even accorded to his own son who had also died earlier that year. Perhaps Thistlewood's greater leniency towards Jimmy also stemmed from pragmatic motives. Jimmy, purchased in 1765 for the sum of $£ 51.00$ represented a prime capital investment. On Thistlewood’s death in November 1786, Jimmy then aged 32, was appraised at $£ 130.00$, the most valuable of all Thistlewood's enslaved people.

\section{Conclusions}

Thistlewood's journal offers only rare glimpses into his inner life, and even fewer into the inner worlds of the enslaved people who populated his world. (Burnard 2004, p.27) An unreflexive diarist, Thistlewood rarely considered or sought to understand the self-motivations of his enslaved people. Hence, he rarely explicates the specific circumstances of Jimmy's moments of resistance, and most frustratingly he 
sheds little light on how Jimmy viewed their mutually antagonistic relationship, or why he chose to reject the privileges of his position as a house servant. Nevertheless, Thistlewood's journal illuminates the trajectory of anti-slavery consciousness of the adolescence enslaved, and their responses to their conditions. Enslaved adults were not the sole victims of slavery, for biological immaturity did not confer immunity from the system's brutal forces. Slavery reached deep into and acted upon the lives of children and young people, and they learned to react to its dehumanising and traumatizing tendencies. For Jimmy, that trauma was more severe in the absence of kin and family in Jamaica. It is possible that Jimmy’s initial seeming accommodation to slavery, and his later descent into alcoholism, were but the outward manifestation of psychological trauma. As he moved into adolescence, and as that trauma was blunted, Jimmy showed himself unwilling to accept Thistlewood's mastery. His opposition was sufficiently disruptive that Thistlewood eventually responded by ejecting Jimmy from his privileged position.

Thistlewood's journals offers rich insights into the processes of transformation of enslaved children to adolescents and mature adults and upon adolescents' negotiations with, manipulations of, and resistance to the master-slave relationship. Scant though they are, the few traces of Jimmy's life revealed in Thistlewood's journal are of interest to historians of slavery and childhood. Few plantation journals of the Caribbean region afford the opportunity to follow in any depth the life of an enslaved individual from childhood to adulthood. We can follow Jimmy from his purchase as a young frightened and confused ten year old youth, into his turbulent adolescence, and into his adult world as a husband and father. If nothing else, Jimmy's life forces us to think about how we might situate enslaved children within the histories of childhood and adolescence from which they have hitherto been 
excluded. Adolescence for Jimmy was a particularly painful period, and probably made more so in the absence of a biological family from whom he could draw comfort. Jimmy may not have been typical of other enslaved adolescents - it would be of interest to explore, for instance, how gender shaped the resistance possibilities of girls and young women, but his responses to enslavement as he arrived at adolescent consciousness of his situation does illuminate the fact that far from being the passive objects of planter mastery, enslaved youths such as Jimmy actively strove to achieve a degree of agency in shaping their own histories. While not always successful, his adolescent confrontations with his master nevertheless forced Thistlewood to recognise his innate humanity. Certainly, Jimmy stands as evidence of the ability of enslaved people to confound their owners' ambitions and expectations of enslaved people. In Thistlewood's case, Jimmy’s innate desire for self-hood potently undermined Thistlewood's belief in the malleability of adolescents as pliable workers. In other words, Thistlewood tried his best to train the child Jimmy to be a proper slave but in adolescence he turned out to be an enslaved person who insisted on his humanity, with a mind of his own, who sought out (at some psychic and physical cost - drunkenness being the psychic and having to work in the fields being the physical consequence) autonomy and independence from Thistlewood. In short, Thistlewood's people were not the malleable slaves he wanted them to be, and it was adolescence that was the turning point where enslaved people's individuality, humanity and resistance to enslavement became clear. Despite being a favourite slave with privileges denied to others, Jimmy proved himself unwilling to subsume himself to Thistlewood and to Thistlewood's ego, even when this course of action entailed considerable personal disadvantages. In the final instance, Thistlewood's journal reveals the ability of enslaved young people to resist the totalising forces of 
enslavement, to refuse to accept the erasure of their humanity, but instead to create their own identities, to survive with dignity, and in the process to act as agents of personal, social and cultural change.

\section{References}

Trevor Burnard (2004), Mastery, Tyranny and Desire: Thomas Thistlewood and his slaves in the Anglo-Jamaica world, University of North Carolina Press, Chapel Hill.

Paul Edwards, ed. (1967), Equiano’s Travels: His Autobiography - The Interesting Narrative of The Life of Olaudah Equiano or Gustavas Vassa The African, Written by Himself. London: Heinemann.

Douglas Hall (1989), In Miserable Slavery: Thomas Thistlewood in Jamaica, 17501786, Macmillan Caribbean/Warwick University Caribbean Studies

Cecily Jones (2006), “Suffer the Little Children': Setting a research agenda for the study of enslaved children in the Caribbean colonial world", Wadabagei: a journal of the Caribbean and it's Diasporas, (vol.9, issue 3)

Wilma King (1995), Stolen Childhood: Slave youth in Nineteenth Century America, Indiana University Press, Bloomington and Indianopolis

Moira Ferguson, ed. (1997), The History of Mary Prince: A West Indian Slave, related by herself. Rev. ed. Ann Arbor: University of Michigan Press.

Inniss, Tara. A. (2005), Children, Sexuality and Sexual Abuse during Slavery and the Apprenticeship Period, 1790-1838. (Paper presented at the annual meeting of the Society for Caribbean Studies Conference, Newcastle).

Salih, Sarah. ed. (2000). The History of Mary Prince. London: Penguin Classic.

\footnotetext{
${ }^{1}$ All quotations from Thomas Thistlewood are derived from his Jamaican journal compiled between 1750 and 1786, archived in the Lincolnshire County Archives, Lincoln, in 37 volumes as Monson 31/1-37. My grateful thanks to Trevor Burnard for making Thistlewood's journal available to me.

${ }^{2}$ Thanks to Trevor Burnard for his insightful comments on the first draft of this paper, especially his encouragement to explore respectively, the psychologies of slavery, and adolescence. Limitations of space mean that I have not been able to incorporate all his suggestions but I would refer readers to the following texts for supplementary reading. On the psychology of slavery I recommend; Ira Berlin (1998), Many Thousands Gone: The First Two Centuries of Slavery (Cambridge: Belknap Press of Harvard University Press); John Blassingame (1979) The Slave Community: Plantation Life in the Antebellum South New York, NY: Oxford University Press, 1979); Alex Bontemps (2001) The Punished Self:
} 
Surviving slavery in the colonial south, Cornell University Press; Ron Eyerman (2001), Cultural Trauma: Slavery and the formation of African-American identity (Cambridge University Press); Michael A. Gomez (1998), Exchanging Our Country Marks: The Transformation of African Identities in the Colonial and Antebellum South (Chapel Hill: University of North Carolina Press); James Sidbury, Ploughshares Into Swords: Race, Rebellion and Identity in Gabriel's Virginia, 1730-1810 (New York: Cambridge University Press, 1997); and Philip D. Morgan, Slave Counterpoint: Black Culture in the EighteenthCentury Chesapeake and Lowcountry (Chapel Hill: University of North Carolina Press, 1998). On the history of childhood and adolescence, see Harvey J. Graff, "Interdisciplinary Explorations in the History of Children, Adolescents, and Youth-For the Past, Present, and Future,” Journal of American History 85 (March 1999): 1538-47; Hugh Cunningham, Children and Childhood in Western Society Since 1500 Stephen Mintz 92004), Huck's Raft: A History of American Childhood, Belknap Press of Harvard University Press. Scholarship on enslaved children in the British colonial world remains severely neglected and underanalysed within Caribbean slave historiography, but a useful starting point is Gwyn Campbell; Suzanne Miers; Joseph C. Miller (eds.) Special Issue: Children in European Systems of Bondage Slavery and Abolition: a journal of slave and post slave studies, Volume 27, Issue 2, August 2006 which focuses specifically on enslaved children in the colonial world. Also useful is McNee, Lisa. 2004. The Languages of Childhood: The Discursive Construction of Childhood and Colonial Policy in French West Africa. African Studies Quarterly 7 (4): 20-32. 